bp Kazimierz Romaniuk

\title{
„Płaczcie z tymi, którzy płaczą” (Rz 12, 15)
}

Zasadniczo trzy stany ducha ludzkiego bywają przyczyną płaczu:

- smutek,

- złość,

- radość.

1. Smutek, którego zewnętrznym wyrazem są łzy, najczęściej jest powodowany utratą jakiegoś, zwłaszcza znacznego dobra, przez co należy rozumieć nie tylko utratę pieniądza, lecz także dobrego imienia - sprawa obecnie bardzo aktualna w związku z procesami lustracyjnymi - z czym wiąże się także zmiana na gorsze dotychczasowej pozycji życiowej poszkodowanego i jego najbliższych.

Uczucie smutku łzy nam wyciska, jednak głównie utrata drogiej nam osoby. Oto, jak zareagowali chrześcijanie, podopieczni Pawła, na przekazaną im przez apostoła wiadomość, że już się więcej nie zobaczą: „Wybuchnęli wielkim płaczem. Rzucili się Pawłowi na szyję i całowali go, smucąc się nade wszystko z tego, że - jak powiedział im - nigdy go już nie zobaczą" (Dz 20, 37n). Zdecydowana większość tekstów biblijnych mówiących ołzach i płaczu dotyczy śmierci naszych bliskich. Jezus też zapłakał nad grobem ukochanego Łazarza (J 11,35), przyłączając się zresztą do płaczu zebranych tam ludzi (11, 33). Kiedy zmarła córka Jaira, powstało wielkie zamieszanie, któremu towarzyszył płacz wielki i zawodzenie (por. Mk 5, 38). Kiedy Piotr przybył pewnego dnia do Jaffy, ,zaraz otoczyły go wdowy, pokazując ze łzami w oczach chitony i suknie, które zrobiła Dorkas jeszcze za życia” (Dz 9, 39).

Biblia mówi również o jakby zbiorowym płaczu ludzi, którzy stracili własną ojczyznę i zostali skazani na wygnanie. Psalmista tak oto ubolewa: „Płakaliśmy, siedząc nad rzekami Babilonu, płakaliśmy myśląc o Syjonie. Nasze harfy zawiesiliśmy na wierzbach tamtego kraju. [...] Lecz jak możemy śpiewać pieśń Pańską, skorośmy tak daleko, na obcej ziemi?” (Ps 137, 1-2. 4). Niejeden, nawet zahartowany w boju żołnierz polski nie był w stanie powstrzymać się od płaczu w dniu podpisywania kapitulacji na początku drugiej wojny światowej albo gdy trzeba było składać broń po upadku powstania warszawskiego. 
Ale jest jeden bardzo szczególny smutek spowodowany niezwykłą utratą: chodzi o nasze dobrowolne pozbawienie się kontaktu z Bogiem, a w konsekwencji narażenie się na utratę ojczyzny, która jest w niebie. Tak płaczący zasługują na pochwałę. Czytamy we wprowadzeniu do Kazania na Górze: „Błogosławieni wy, którzy teraz płaczecie” (Łk 6, 21). Niewiasta jawnogrzesznica, świadoma swoich upadków, gdy znalazła się przed Jezusem, „płacząc przy Jego stopach, zaczęła je obmywać łzami” (Łk 7, 38). Ewangelista Łukasz podaje, że dnia pewnego „Jezus, gdy zbliżył się i zobaczył miasto, zapłakał nad nim" (Łk 19, 41). Ten płacz był spowodowany wizją ruin Jerozolimy ukaranej za grzechy jej mieszkańców zasługujących wskutek tego na wieczne odrzucenie przez Boga. Podobnie ubolewa Paweł w swym Liście do Filipian: „Jest też wielu takich, którzy pokazują swoim życiem, że są wrogami Chrystusowego krzyża. Mówiłem wam o tym już wiele razy, a teraz powtarzam to z płaczem" (Flp 3, 18). Co więcej, powodowany tą samą, pełną smutku troską o życie wieczne chrześcijan korynckich, Paweł napisał do nich odezwę apostolską zwana inaczej „listem we łzach”. Tak to pismo wspomina: „Pisałem bowiem do was będąc w wielkiej rozterce i ucisku serca, wśród wielu łez, nie po to, aby was zasmucić, lecz, żebyście wiedzieli, jak tym bardziej was miłuję" (2 Kor 2, 4). Kojarzą się tego rodzaju wypowiedzi ze łzami Matki Bożej z głośnych objawień prywatnych także w naszych czasach. Matka Boża płacząca nad grzechami ludzi. W sytuacji tego rodzaju prawdziwie święci po dzień dzisiejszy proszą Boga o łaskę łez jak najobfitszych. Są to łzy szczerego żalu za grzechy. Nic nie powinno nas zasmucać tak bardzo, jak utrata Boga. Biblia mówi, że Piotr uświadomiwszy sobie, jak wielkie zło uczynił, zapierając się Jezusa, gorzko zapłakał (por. Łk 22, 62). Według pobożnej legendy ten płacz był tak długotrwały, że od łez potworzyły się bruzdy na policzkach Piotra. Łzy prawdziwego żalu.

Smutek połączony z przerażeniem jest wspominany w opisach sądu ostatecznego. Formuła „płacz i zgrzytanie zębów” pojawia się w tego rodzaju tekstach ewangelijnych aż sześć razy (por. np. Mt 8, 12; 13, 42; Łk 13, 28 itp.).

2. Złość, gwałtowne zagniewanie też mogą być przyczyną łez i głośnego płaczu. Ma to miejsce wtedy, gdy wielkiego podniecenia nie można się pozbyć, czyli rozładować złości w inny sposób. Pojawiają się wówczas tak zwane „łzy bezradności”. Pismo Święte zna też ten rodzaj ujawniania złości, gdy mówi o złym, który patrząc na dobro „boleje, zgrzyta zębami, sinieje” (Ps 37, 12). Nie ma tu co prawda mowy o łzach, ale jest „zgrzytanie zębami” i „zsiniałe oblicze”. Są to sytuacje niebezpieczne. Może wtedy ucierpieć ktoś naprawdę Bogu ducha winny, a sprawca ewentualnej krzywdy ma na wytłumaczenie to, co respektują nawet przepisy prawne: że działał pod wpływem emocji, 
tak że był chwilowo nie w pełni poczytalny. Tym samym zmniejsza się jego odpowiedzialność za dokonane wykroczenie albo nawet zbrodnię.

3. Wreszcie płakać można także z radości. Jak smutek jest zazwyczaj powodowany utratą czegoś lub kogoś, tak radość najczęściej pozostaje w związku z jakimś osiągnięciem. Płaczą ze szczęścia sportowcy w momencie dekorowania ich zwycięskimi medalami albo jeszcze wcześniej, gdy na ich cześć odgrywa się hymn narodowy; rzucają się sobie w objęcia zdobywcy najwyższych szczytów świata; cała rodzina nie ukrywa łez radości, gdy ojciec szczęśliwie wraca z wojny; płaczą ludzie odwiedzający swoją ojczysta ziemię po długoletnim pobycie na obczyźnie; pątnicy odbywający piesze pielgrzymki na Jasną Górę płaczą dostrzegając po raz pierwszy strzelistą wieżę częstochowskiego sanktuarium; nie ukrywają swoich łez, gdy już znajdą się w cudownej kaplicy i przeżywają odsłonięcie obrazu Matki Bożej, czemu też sprzyjają przejmujące dźwięki odgrywanego hejnału.

4. To chyba prawda, że niewiasty są bardziej skłonne do płaczu niż mężczyźni. Nikt też nie zwykł się gorszyć płaczem kobiety; przeciwnie, te łzy są wyrazem niewieściej wrażliwości, czyli tego, na co nawet nie jest w stanie zdobyć się wielu mężczyzn. W Biblii też najczęściej płaczą niewiasty. Niewiasty płakały na widok dźwigającego krzyż Jezusa (por. Łk 23, 27). Nad grobem Jezusa stała i płakała Maria Magdalena (por. J 20, 11).

Trochę inaczej w naszym kręgu kulturowym rzecz się ma z płaczem mężczyzn. Uważają niektórzy, że prawdziwemu mężczyźnie łzy absolutnie nie przystoją. O płaczącym mężczyźnie mówi się, że to mazgaj, niedojda, osobnik absolutnie zniewieściały itp. Taki zbyt łatwo wzruszający się mężczyzna z pewnością sam może przyznać, że spływające po policzkach łzy, i to w momentach najbardziej niewskazanych, utrudniają publiczne wystąpienia, przy tym nie zawsze wzruszają słuchaczy, ale wręcz przeciwnie, przyczyniają się do ośmieszenia mówiącego; wreszcie walka z pojawiającymi się łzami utrudnia poprawne rozumowanie, a nawet samo wypowiadanie poszczególnych wyrazów.

Ale tak naprawdę łzy, nawet w przypadku mężczyzny, nie stanowią jego pohańbienia. Przeciwnie, świadczą o pewnej szlachetności płaczącego, o jego dobrym, wrażliwym sercu. O nigdy nie płaczących mężczyznach zwykło się mówić, że „są wyprani z wszelkich uczuć”. Takie powiedzenie to z pewnością nie jest komplement.

5. Według Pisma Świętego w przyszłym życiu sprawiedliwych nie będzie ani płaczu, ani smutku. Czytamy w ostatniej księdze Pisma Świętego: „Oto przybytek Boga wśród ludzi. Zamieszka razem z nimi. Oni staną się Jego narodem, a On będzie Bogiem z nimi. On otrze z ich oczu wszelką łzę. Nie będzie już odtąd śmierci ani żadnego smutku, ani narzekań, ani utrudzenia” (Ap 21, 3n). Znaczy to przede wszystkim, że zbawieni nie będą mieli 
żadnego powodu do smutku. Nie będą płakać ze smutku, z przygnębienia. Zrozumiałe też, że nie będą płakać ze złości i zagniewania. Nie będzie po temu żadnych powodów.

Pismo święte nie mówi co prawda o tym, że obdarzeni szczęściem wiecznym będą płakać z radości, jaką daje oglądanie Boga twarzą w twarz. Ale takie łzy szczęścia wcale by nas nie dziwiły, gdyby się znalazły w opisach pozagrobowej egzystencji usprawiedliwionych.

Człowiek nie jest samotna wyspą. Nawet wbrew własnej woli dzieli ze swym otoczeniem nie tylko radości, lecz także smutki. Apostoł Paweł słowami zacytowanymi w tytule niniejszych rozważań wyraźnie nas do tego zachęca. Taka postawa powinna zresztą być naturalnym następstwem naszego przynależenia do Kościoła, który jest szczególną zbiorowością wielu jednostek. Ludzie tworzący Kościół nie idą przez życie w pojedynkę. Potrzeba jakby trzymania się za ręce z bliźnimi wynika z programu, który jest zawarty w kształtach krzyża Chrystusowego: ramię pionowe pokazuje, dokąd mamy zmierzać. Odpowiedź brzmi: ku górze, bo tam jest nasza ojczyzna. Ramiona poziome to odpowiedź na pytanie, jak mamy odbywać tę podróż do niebieskiej ojczyzny. Odpowiedź brzmi: w ścisłej łączności z braćmi. Być żywą cząstką Kościoła to znaczy „radować się z tymi, którzy się radują, i płakać z tymi, którzy płaczą". 